\title{
Entre o quinino e a cloroquina: ecos da gripe espanhola na cobertura jornalística sobre a pandemia no Brasil
}

\section{Adriana Santana'}

\section{Resumo}

Este trabalho é fruto da investigação da produção de jornais e revistas brasileiros no período de 1918 a 1919, quando da eclosão da pandemia da gripe espanhola. A análise de como os veículos se comportaram à época, indicando permanências e divergências entre a práxis jornalística do início do século passado e a realizada na pandemia do coronavírus em 2020, configura-se como possibilidade de incremento à prática profissional e reflexão sobre a atuação dos jornalistas. Os resultados apresentados são consequência do trabalho de catalogação e análise de edições integrais veiculadas no Brasil entre setembro de 1918 e setembro de 1919, pelo Grupo de Pesquisa Jornalismo e Humor², da Universidade Federal de Pernambuco.

Palavras-chave: Gripe Espanhola. Coronavírus. Pandemia. Jornais

\section{Between Quinine and Chloroquine: Spanish flu echos in midia coverage about the pandemic in Brazil}

\footnotetext{
' Jornalista, mestre e doutora em Comunicação. É professora do Departamento de Comunicação da Universidade Federal de Pernambuco, onde coordena o Grupo de Pesquisa Jornalismo e Humor e o projeto de extensão Fora da Curva, um programa jornalístico de rádio, ao vivo e diário. e-mail: adriana.masantana@ufpe.br

2 Este artigo teve a participação indispensável dos integrantes do Grupo de Pesquisa Jornalismo e Humor: Aliny Agostinho, Carina Barros, Consthanza Oliveira, Gabriela Andrade, Rayane Domingos, Thalys Rodrigo Menezes, Thawane Maria e Vitória Albino.
} 


\section{Abstract}

This paper is the result of the analyses of 1918-1919 Brazilian newspapers and magazines, when the Spanish flu pandemic broke out. An analysis on how the press behave at the time, indicating permanency and divergences between both epochs. It may represent a possibility of increase in professional practice as well as a tool to analyse the role of the press nowadays. The results presented in this article are the result of both cataloging and analyzing published editions in Brazil between September 1918 and September 1919 by the Journalism and Humor Research Group, from the Federal University of Pernambuco

Keywords: Spanish flu. Coronavirus. Pandemic. Newspapers.

\section{Introdução: a 'peste' ao final da guerra}

A profusão de notícias acerca da pandemia do coronavírus - aquelas advindas da produção jornalística calcada na consulta a fontes científicas e referenciadas em coexistência com as chamadas fake news (sem qualquer teor crítico ou consulta a bases confiáveis) - tem sido a tônica do que a Organização Mundial da Saúde (OMS) caracterizou, em boletim epidemiológico, como "infodemia" (OMS, 2020, p.145). O excesso das primeiras, quando muito, pode causar a aversão e o desinteresse ao tema. Já as segundas têm efeito colateral mais grave: podem chegar, em casos extremos, a impulsionar a automedicação, o descuido com as medidas de proteção ao vírus e até a mortes, a exemplo da ingestão fatal de metanol por cidadãos iranianos (UOL, documento eletrônico, 2020).

A imprensa assistiu ao alvorecer do século $X X$ com a eclosão de uma guerra (1914) e, em 1918, ao final do conflito, viu-se às voltas com a pandemia da gripe espanhola. Assim como temos observado na produção jornalística contemporânea, houve um domínio do tema da doença no noticiário, ainda que em menor proporção por conta do quantitativo de veículos e das dificuldades na troca de informações entre o países.

Mesmo sem tanto poder de capilarização e alcance, também no começo do século passado havia a disseminação de informações falsas sobre a pandemia da influenza. Em edição de outubro de 1919, a revista Fon-Fon!, editada no Rio de Janeiro, já criticava a responsabilidade dos jornais na desinformação sobre a gripe espanhola. Com uma ilustração (Figura 1) que mostrava várias embalagens de remédio, alfinetava: "a simples leitura actualmente, duma página de annuncio de jornal, bastará para immunizar da 
'influenza espanhola'. Neste momento, à falta de athrmação (sic) da sciencia, toda droga cura o já célebre mal" (FON-FON, 1918 ).

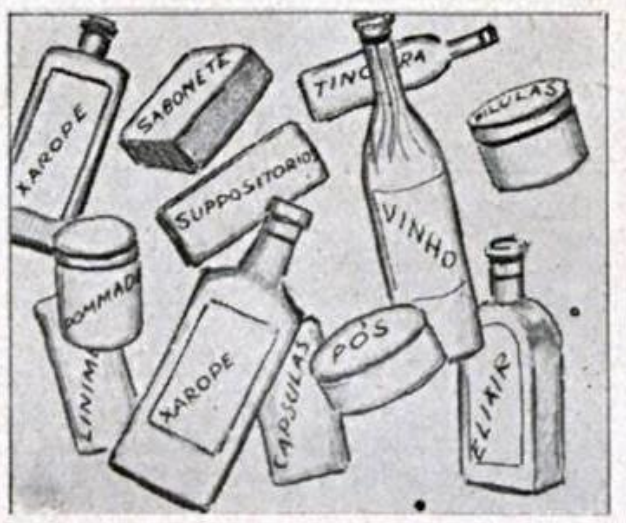

A " influenza ".

A simples leitura, actualmente, duma pagina de annuncio de jornal, bastará para immunizar da "influenza hespanhola ". Neste momento, á falta de afhrmação positiva da sciencia, toda a droga cura o já celebre mal...

Figura 1: llustração da edição 40 da Revista Fon-Fon, de 05/10/1918. Fonte: Coleção Digital de Jornais e Revistas da Biblioteca Nacional

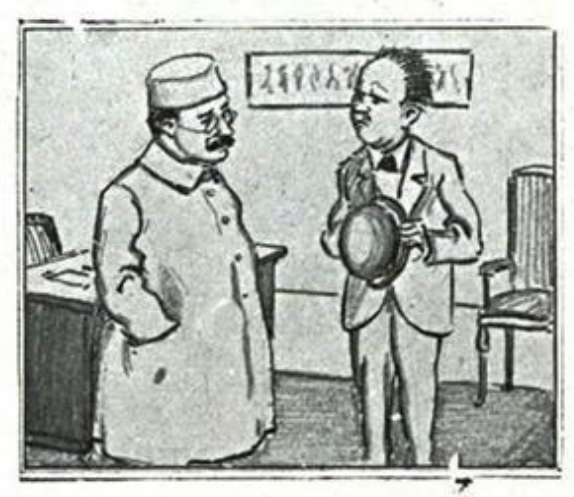

-Ora, doutor! Mas não ha um preservativo contra a whespanholaw?

- Como não? Ha, e excellente : não lèr iornaes...

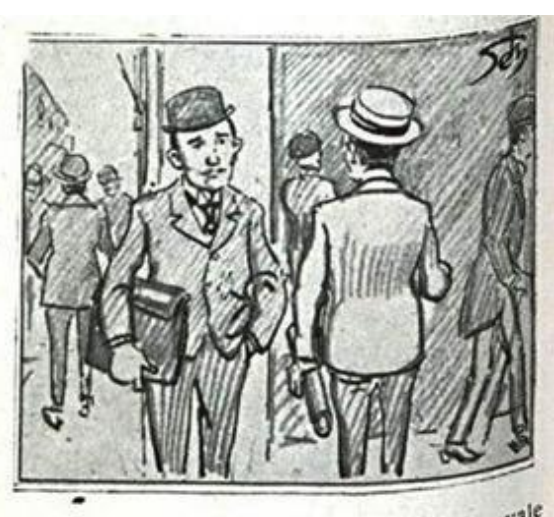

O advogado sem causas - Mais vale advinhar um dia do que ser rei toda a vid me Imagine se eu me tivesse formado em ... dicina! Agora, com a whespanhola

Figura 2: Ilustrações do artista Seth publicadas na edição 42, de 19 de outubro de 1918 da Fon-Fon. Fonte: Coleção Digital de Jornais e Revistas da Biblioteca Nacional. 
Para compreender a crise sanitária da pandemia da Covid-19, resolvemos voltar 102 anos na história do Brasil, mais precisamente para os anos de 1918 e 1919, quando nosso país foi assolado pela influenza. Tal análise nos apontou repetições de equívocos e evoluções alcançadas entre os dois momentos históricos.

Analisamos veículos brasileiros de relevância na cobertura da 'espanhola': as revistas Fon-Fon (RJ), Careta (RJ), A Política (RJ) e Bahia Illustrada (BA), e os jornais Gazeta de Notícias (RJ), Correio Paulistano (SP), O Combate (SP), Jornal do Recife (PE), Correio da Manhã (PE), Diario de Pernambuco (PE), Jornal Pequeno (PE), A Hora (BA) e Correio da Manhã (BA). As edições fazem parte do acervo da Hemeroteca Digital da Biblioteca Nacional.

Quando a doença atingiu o país em 1918, a população brasileira era de aproximadamente 30 milhões de pessoas. A Organização Mundial da Saúde (OMS) calcula que a Grande Gripe foi a pandemia mais mortal da história: 50 milhões de óbitos entre 1918 e 1920 (REVISTA GALILEU, 2020, documento eletrônico). Em alguns dos veículos que nossa pesquisa tomou como base, os números de óbitos não foram informados. No atual cenário, desde junho de 2020, a quantidade das vítimas da Covid-19 é contabilizada na imprensa brasileira por um consórcio de mídia.

A gripe espanhola escancarou a precária situação da saúde no Brasil e a falta de capacidade do governo em lidar com um vírus novo e com alta capacidade de mutação, cenário que vemos se repetir em 2020. Talvez uma das divergências entre as duas pandemias seja naturalmente o grau de desenvolvimento da medicina, já que o vírus responsável pela gripe espanhola só foi conhecido na década de 1930, e a primeira vacina só seria fabricada em 1944 (JANASI, 2020, documento eletrônico).

Em setembro de 1918, quando foram registradas as primeiras pessoas com sintomas, os jornais reportaram de maneira intensa cada caso que aparecia, relatando quem se infectou, onde, e como estava lidando com a doença. De acordo com o que identificamos nas matérias dos periódicos pesquisados, os primeiros casos de brasileiros infectados foram identificados numa missão médica brasileira na cidade de Dakar, no Senegal.

Até o fim do mês de setembro a escassa cobertura sobre a pandemia se resumia ao estado de saúde das tropas brasileiras, notícias de brasileiros que ficaram doentes em outros países e casos internacionais. Nos últimos dias de setembro e começo de outubro, 
contudo, as notícias sobre inspeções sanitárias em portos e tripulantes que chegaram aqui infectados dispararam.

Nos meses de outubro e novembro as notícias sobre a pandemia chegaram ao pico, sendo possível ler textos sobre a nova doença diariamente, em diferentes páginas do mesmo jornal (Figuras 3). Sobre o que eram as notícias e o tom de cada uma é um dado bastante variável, pois normalmente no mesmo jornal era possível ler uma notícia, artigo de opinião, elegrama ou uma nota sobre a pandemia - se não no mesmo dia, certamente na mesma semana.
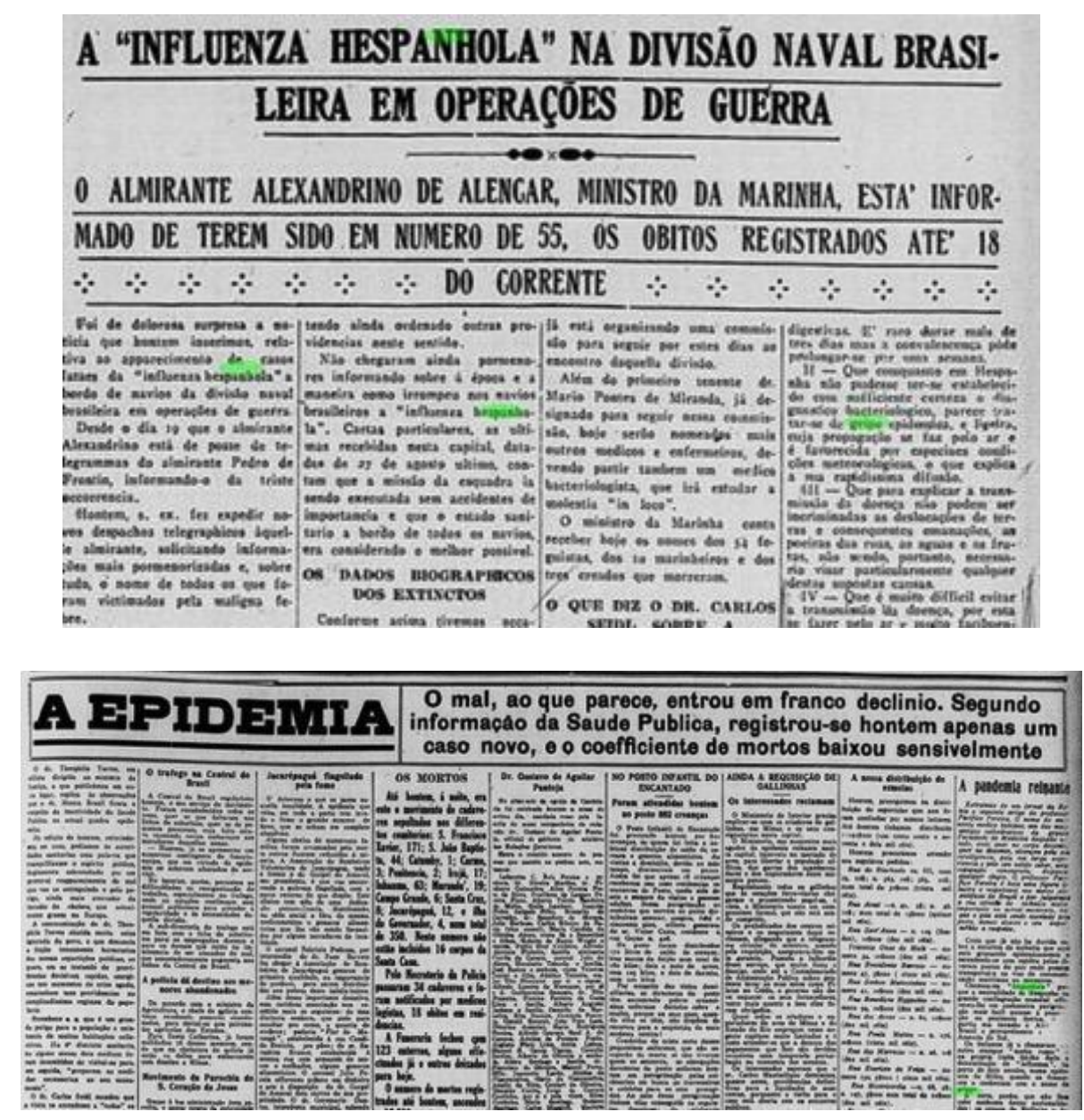

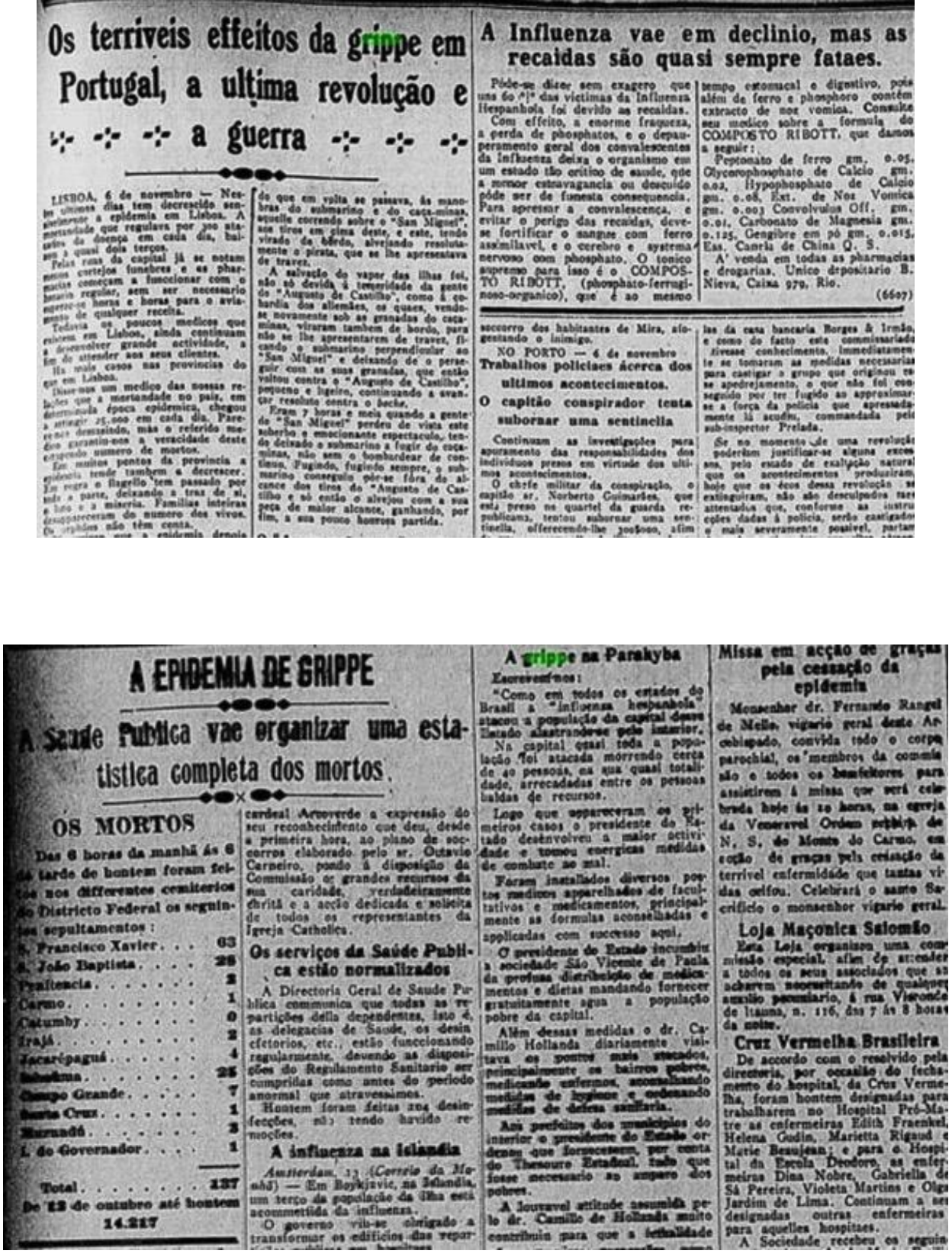

Figuras 3 : Primeiras páginas de edições do Correio da Manhã em que a pandemia era o destaque. Fonte: Arquivos digitais da Biblioteca Nacional

Também foi possível observar nesses dois meses diversas entrevistas, principalmente com o diretor geral de saúde pública à época, Carlos Seidl. Embora no começo da pandemia os jornais tratassem a doença como uma "gripe leve", no período de 
maior pico falas de políticos geralmente eram acompanhadas de críticas ácidas dos jornais à forma como eles lidaram com o vírus.

Os veículos pesquisados traziam uma quantidade considerável de notícias factuais, então era possível ler com frequência listas como obituários, detalhando nome, idade e causa da morte do falecido. Telegramas vindos de outros países também eram muito frequentes e se configuravam como a principal fonte de informação sobre o que estava acontecendo fora do Brasil.

A partir de dezembro de 1918 as notícias sobre a ainda vigente pandemia se tornaram mais escassas. As raras menções à doença agora apareciam quando uma missa em homenagem a algum morto acontecia ou comparando a doença (sempre usando o tempo passado) com algum problema do momento. No ano de 1919 as notícias praticamente desapareceram.

\section{A espanhola em solo brasileiro}

O vírus da gripe espanhola chegou ao Brasil pelo mar, mais precisamente a bordo do navio Demerara, que fazia correio marítimo. A embarcação partiu de Liverpool, na Inglaterra, fez escala em Lisboa, em seguida em Dakar, e entrou no país pelo estado de Pernambuco, pelo porto do Recife. De lá, seguiu para Salvador, de onde partiu para o o Rio de Janeiro e São Paulo. Esse foi o caminho da entrada da pandemia em solo brasileiro, conforme acompanhamos pela leitura dos jornais da época e em comunicado publicado na primeira página do Correio Paulistano de 16 de outubro de 1918 (CORREIO PAULISTANO, 1918, p.1).

Os 13 jornais e revistas pesquisados tiveram, de início, um certo cuidado para alertar a população sobre os riscos de contaminação da gripe. Evitar aglomerações, cuidados com a higiene e $\mathrm{o}$ isolamento social eram as principais mensagens que a imprensa repassava para informar os leitores acerca dos riscos da chegada do novo 'inimigo' para além da primeira grande guerra, que já dava sinais de fim.

Sem perspectiva de vacina, reinavam as mezinhas, 'tratamentos' que surgiam entre a população, indicando quinino, enxofre, pimenta, limão, glicerina, conhaque, balas ou sal de uvas como 'cura' da doença (Figura 4). Quem não tinha condições para adquirir 
esses produtos fazia uma mistura de cachaça, mel e limão, que passou a ser conhecida como caipirinha (WESTIN, 2018, documento eletrônico).

Teorias conspiratórias como a de que "o vírus é benigno" ou "a gripe nos quartéis não é a espanhola" eram boatos que se disseminavam com rapidez.

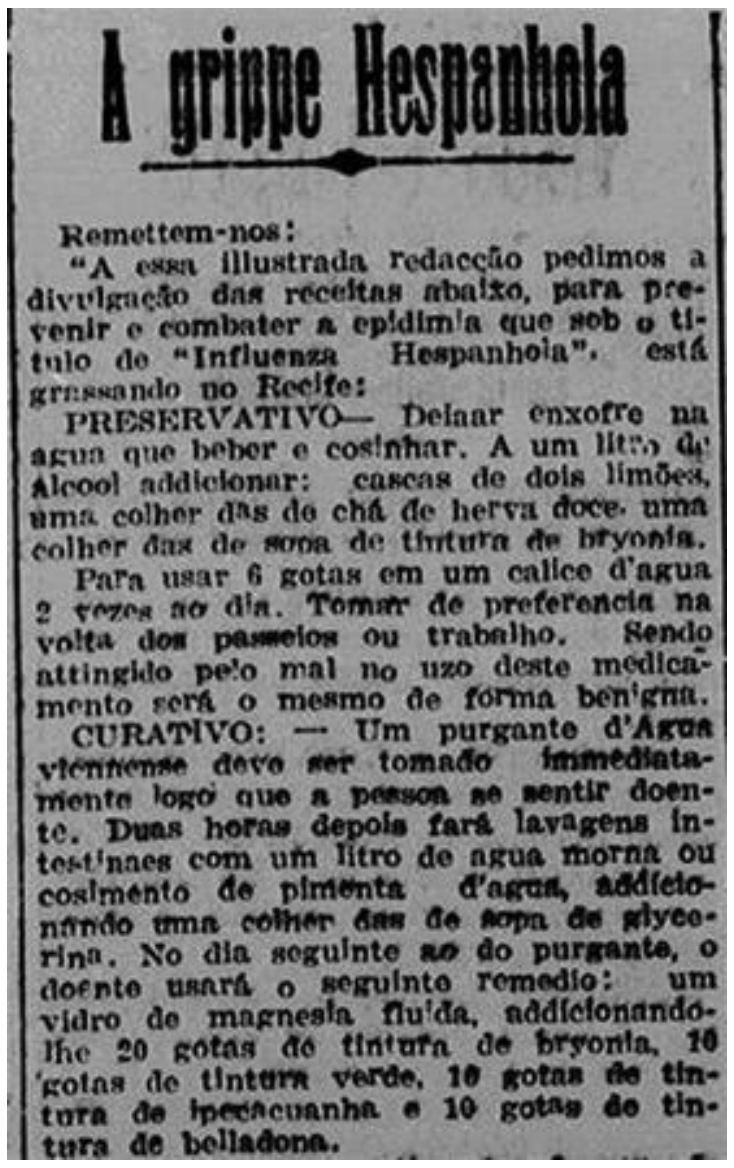

Figura 4 - Capa do Diario de Pernambuco de 04 de outubro de 1918 estampava pedido de divulgação de receitas "para prevenir e combater a epidemia que sob o título de "Influenza Espanhola" está grassando no Recife". Fonte: catalogação do Grupo Jornalismo e Humor nos arquivos digitais da Biblioteca Nacional

É perceptível, com a leitura atenta aos jornais da época e à cobertura de agora, que há a recorrência de que opiniões ligadas ao senso comum, sem nenhuma comprovação científica, acabam se misturando aos dados e descobertas da Ciência, de modo que a propagação de informações falsas não é uma novidade, apenas conta com mais capilaridade e velocidade em tempos de pandemia e redes sociais digitais. 
O Jornal Pequeno, que circulava na cidade do Recife, publicou, na edição de 07 de setembro de 1918, carta do inspetor sanitário Ribeiro de Castro, na qual alertava a população sobre como o vírus vinha assolando e de que era necessário evitar que a gripe atingisse um certo número de vítimas, pois no Brasil, Europa e em nenhuma parte do globo civilizado haveria uma repartição pública de higiene capaz de executar essa tarefa:

Não se trata aqui de uma defesa, mas de uma verdade, acima de qualquer contestação. É necessário evitar as causas de fadiga, os resfriados, as visitas aos doentes e aglomerações, é preciso ter cuidado da higiene da garganta e das fossas nasais. Usar limão ou conhaque só se quiserem ou tiverem fé." (JORNAL PEQUENO, 1918, primeira página)

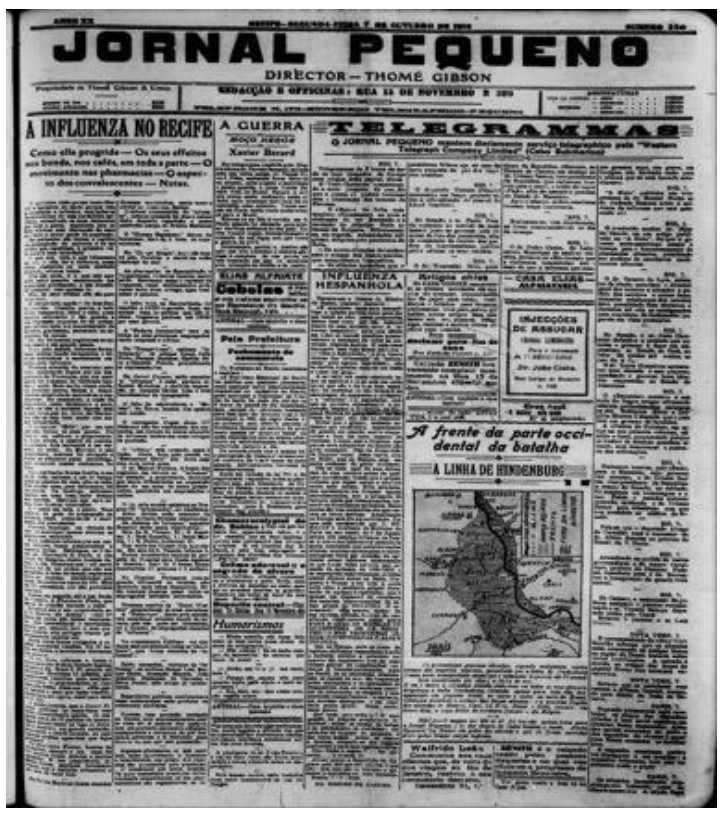

Figura 5: Fac-simile da edição 230 do Jornal Pequeno, de 07/09/1918. Fonte: catalogação do Grupo Jornalismo e Humor nos arquivos digitais da Biblioteca Nacional

Além do conteúdo editorial muitas vezes destacar tratamentos caseiros, sem qualquer comprovação científica, 'reclames' e anúncios eram frequentes de produtos com promessa de solução para o mal, como o anunciado no Jornal Pequeno de 17 de outubro de 1918: 


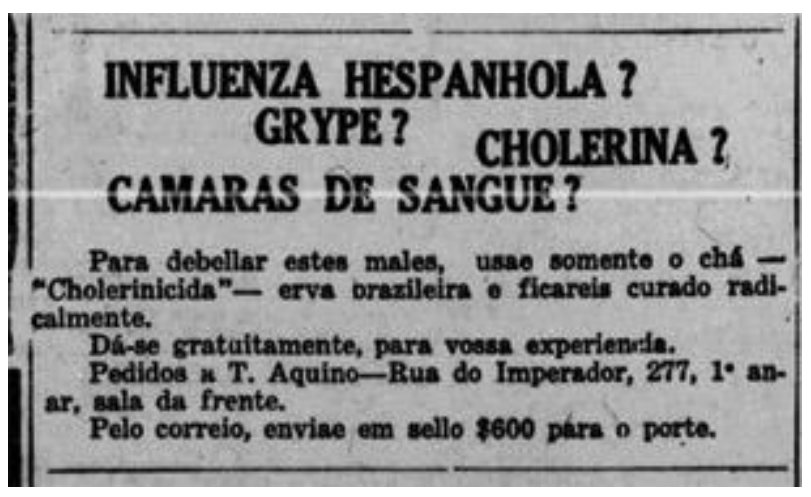

Figura 6: Anúncio de chá (Cholerinicida) contra a gripe espanhola na edição 286 do Jornal Pequeno, de 17/10/1918. Fonte: Arquivos digitais da Biblioteca Nacional

Uma das consequências da gripe espanhola bastante evidenciada nos veículos da época era a queda de cabelo. O mesmo jornal publicou um anúncio, em 15 de junho de 1919, visando às pessoas que se queixavam de queda capilar após a recuperação mulheres, na maioria dos casos. No anúncio há o seguinte título - "O medo não é da Gripe é da careca!" - e indicações sobre um tônico para evitar a queda de cabelo e caspa.

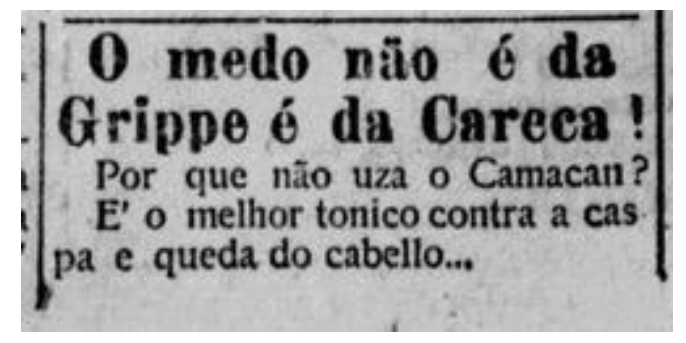

Figura 7: Anúncio na edição 134 do Jornal Pequeno, de 15/06/1919. Fonte: catalogação do Grupo Jornalismo e Humor nos arquivos digitais da Biblioteca Nacional

Em outubro de 1918, a revista Bahia Illustrada publicava artigo referente ao crescimento do contágio da gripe espanhola no Rio de Janeiro, informando que o mal já

havia dizimado mais de 11 mil pessoas. O veículo detalha todo sofrimento que a influenza causou à época. A gripe era também chamada de "pandemônico" nas publicações, devido 
às dores anônimas e confusas que geravam um desânimo que levou alguns casos clínicos ao diagnóstico de loucura, bem como suicídios e mortes imediatas reportados. Foi uma tragédia de calamidade pública que deixou ecos até hoje. Há registros, nos jornais e revistas, da realização de diversas procissões nas ruas, com fervorosas invocações para a cura.

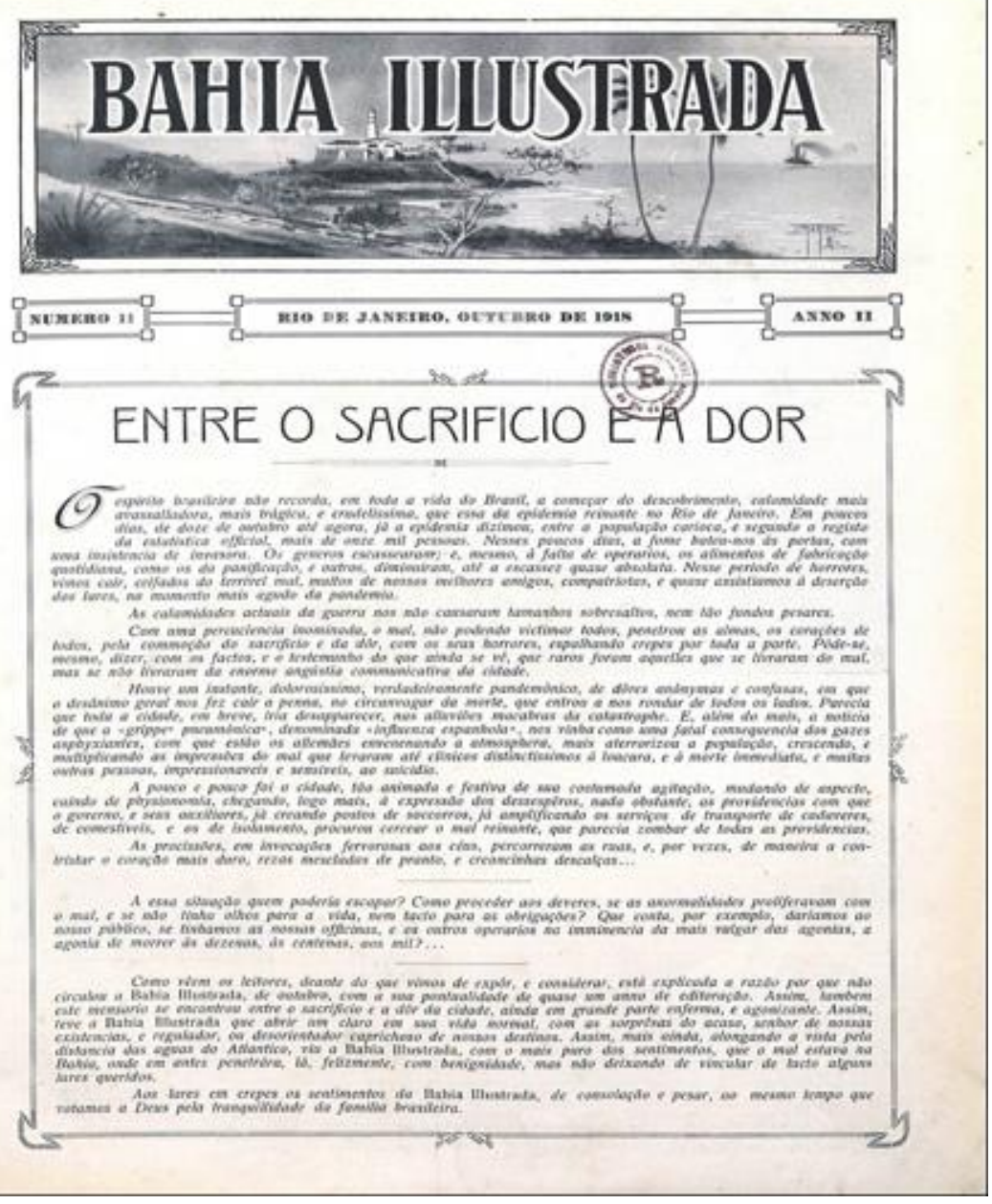

Figura 8: Revista Bahia llustrada, edição de outubro de 1918. Fonte: Arquivos digitais da Biblioteca Nacional

A seção "Página Feminina" da Bahia Illustrada, na mesma edição, comemorava um ano e relembrava que o beijo poderia ser uma das causas do contágio da gripe. 
Também informava que em diferentes lugares a moléstia tomava diversos nomes (Figura 9).

Pelo horror que todos os países Ihes tem cada um lhe dar uma origem estrangeira: Febre Siberiana, Febre chinesa, Febre russa, são nomes da velha grippe aos quais se juntam agora os dois postos em voga pelos jornais de todo o mundo: influenza espanhola e mal de Dakar.

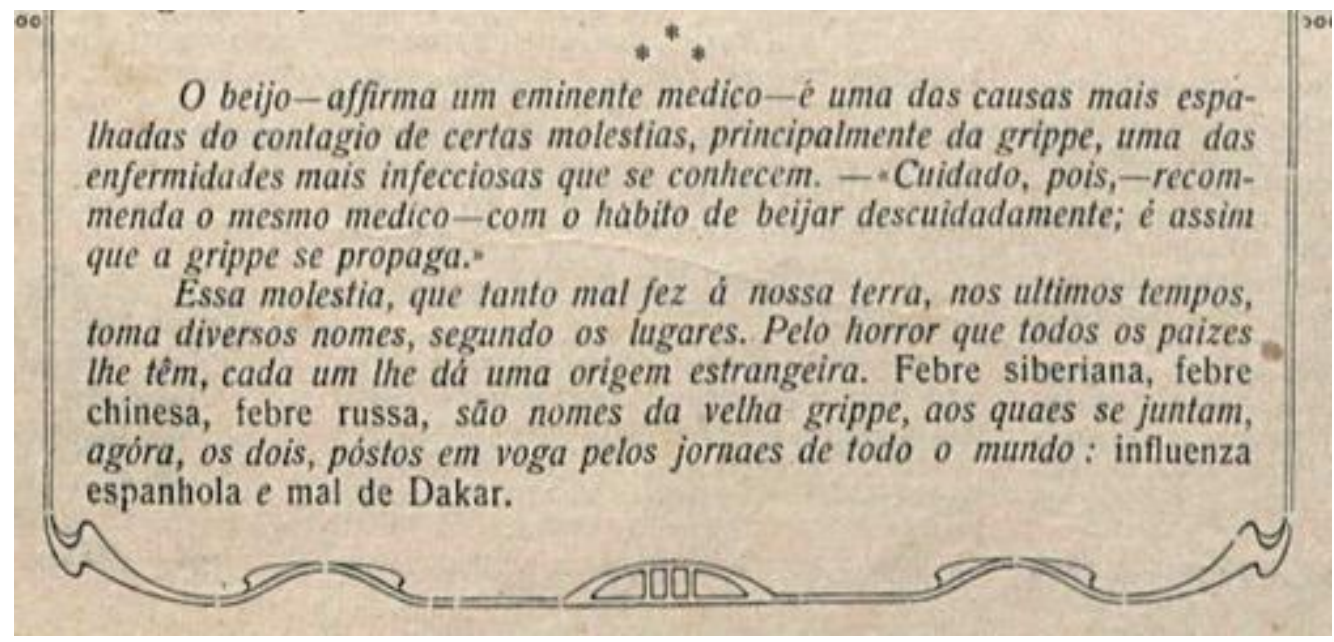

Figura 9: Artigo da Revista Bahia llustrada de 1918. Fonte: Arquivos digitais da Biblioteca Nacional

\section{A gripe, números e a administração pública}

Uma fonte importante para se dimensionar a eclosão da pandemia na gripe espanhola no país são os relatórios dos então governadores dos Estados brasileiros. Para este artigo, analisamos mensagens dos representantes dos estados de Pernambuco e Bahia, também disponíveis nos arquivos da Biblioteca Nacional.

Em relatório de 06 de março de 1919, do então governador do Estado de Pernambuco, Manoel Antônio Pereira Borba, endereçado ao Congresso Legislativo, havia informes sobre a situação sanitária da penitenciária pernambucana durante a invasão da influenza. No trecho destacado abaixo (Figura 10), consta que o Estado sofreu bastante no ano corrente (1918), pois o vírus se alastrou entre os detentos, com 348 doentes: 313 tiveram alta, 11 permaneciam em tratamento e 24 faleceram: 


\section{Estado sanitario}

E' tambem muito satisfactorio o estado sanitario desse estabelecimento, pois du. rate 0 anno u.timo em que soffreu este Estado a invasio, em caracter epidenico, da gripje ou "influenza bespanhola", tendo baixado à enfermaria, durante aquelle lopso de tempo, 318 doentes, inclusive 206 grippados, tiveram alta 313 e openas fal. leceram 24, existindo ainda em tratamento 11.

Sio esses os informes que, em synthese, vos posso ministrar sobre a situaçåo actual de nosa penitenciaria.

No relatorio já citado e a ser impresso, o qual em tempo vos sera distrihuido, encontra.eis outras informaçủes mais minuciosas sobre esse departamento publico.

Figura 10: Relatório do Presidente do Estado de Pernambuco ao Congresso Legislativo de 06/03/1919. Fonte: Arquivos digitais da Biblioteca Nacional

Já o governador do Estado da Bahia à época, Antônio Ferrão Moniz de Aragão, informava que o Estado teve que pagar tributo por conta da epidemia da gripe, mas que em seu estado a gripe havia sido mais benigna e menos expansiva. A contaminação em solo baiano teria se iniciado no dia 27 de setembro de 1918, de acordo com o documento, avançando no mês de outubro e seguindo para declínio em 30 de Novembro.

Foram registrados pelas estatísticas sanitárias da capital, Salvador, em toda a zona urbana e suburbana, 338 óbitos por gripe, o que implica numa média diária de 5,2 óbitos entre os 320 mil habitantes à epoca da capital da Bahia. Aproximadamente 130 mil contraíram a doença, o que representou porcentagem de óbitos igual a 0,26\%. A epidemia continuou a se expandir e houve mais casos em dezembro, especialmente nos subúrbios, onde foram registrados ainda 33 óbitos. 
Mortalidado goral o da grippe

\begin{tabular}{|c|c|c|c|c|c|c|c|}
\hline \multirow[b]{2}{*}{ anzess } & \multicolumn{3}{|c|}{ Mortalladade Eerest } & \multicolumn{4}{|c|}{ Mortalladede de serippo } \\
\hline & $\begin{array}{l}1 \\
\mathbf{z}\end{array}$ & 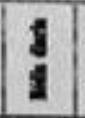 & 1 & 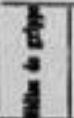 & $\begin{array}{l}y \\
y\end{array}$ & 售 & I: \\
\hline $\begin{array}{l}\text { Setembro........... } \\
\text { Outabro........... } \\
\text { Noverabra........ } \\
\text { Somma....... }\end{array}$ & $\begin{array}{r}460 \\
858 \\
5 n \\
1.000\end{array}$ & $\begin{array}{l}15.3 \mathrm{~s} \\
27.5 \mathrm{~s} \\
19 . \mathrm{s3} \\
20.72\end{array}$ & $\begin{array}{l}17.50 \\
31.48 \\
21.72 \\
23.65\end{array}$ & $\begin{array}{r}10 \\
236 \\
93 \\
399\end{array}$ & \begin{tabular}{l|}
0.33 \\
7.61 \\
3.10 \\
3.72
\end{tabular} & \begin{tabular}{l|}
0.30 \\
3.69 \\
3.50 \\
4.25
\end{tabular} & $\begin{array}{l}2.17 \\
27.60 \\
16.28 \\
17.97\end{array}$ \\
\hline 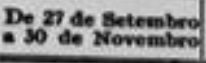 & 1.495 & 23.00 & 26.25 & 338. & 5.20 & & 22.60 \\
\hline
\end{tabular}

Figura 11: Tabela com dados de mortalidade da gripe espanhola em relatório do Congresso Legislativo do Estado da Bahia de 1919. Fonte: catalogação do Grupo de Pesquisa Jornalismo e Humor nos arquivos digitais da Biblioteca Nacional

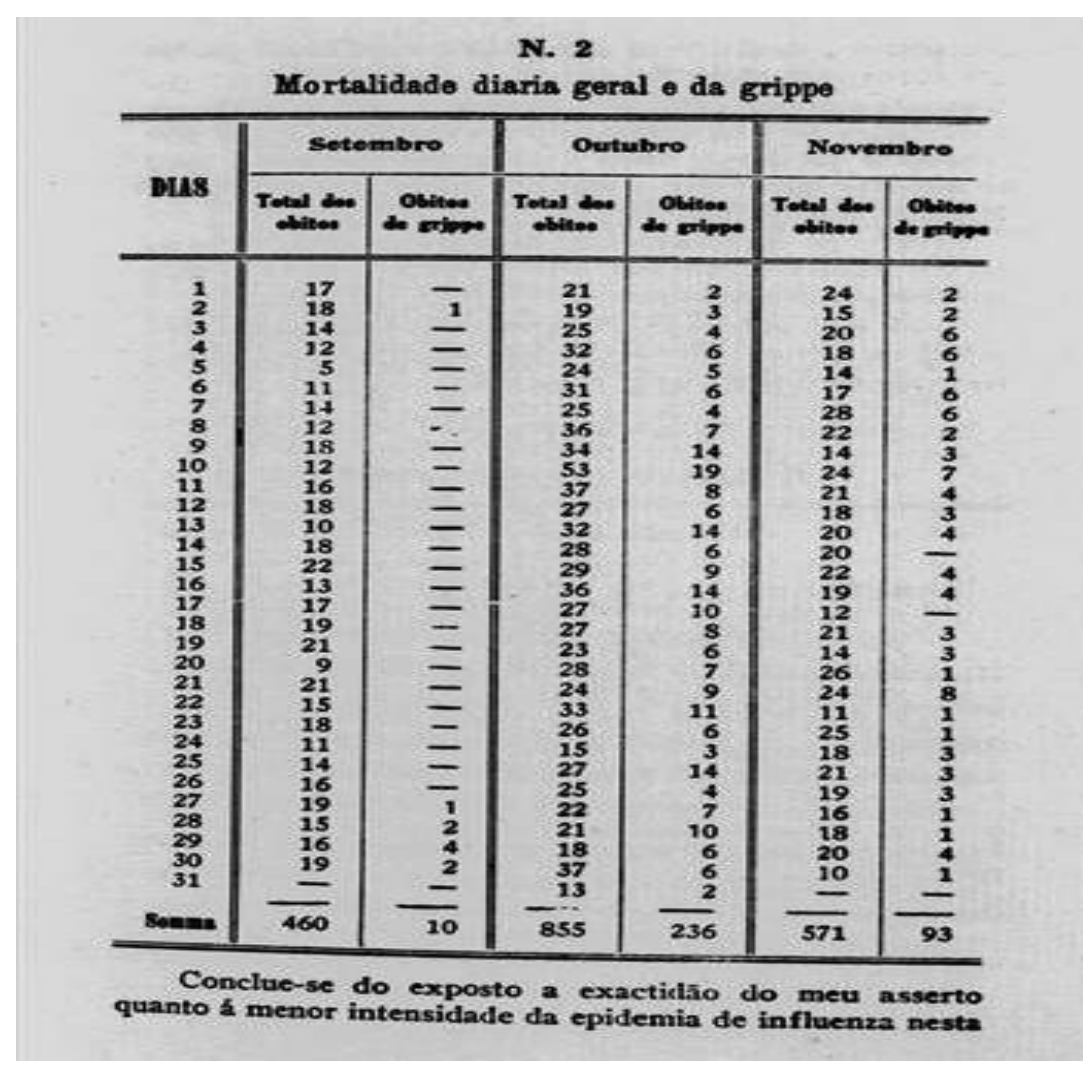

Figura 12: Tabela com dados de mortalidade diária geral e da gripe espanhola do relatório do Congresso Legislativo do Estado da Bahia de 1919. Fonte: catalogação do Grupo de Pesquisa Jornalismo e Humor nos arquivos digitais da Biblioteca Nacional 
No Estado de São Paulo, durante os meses de outubro, novembro e dezembro, registraram-se 5.328 óbitos produzidos pela gripe, quantidade 14 vezes maior do que no estado da Bahia. De 27 de setembro a 31 de dezembro, 371 casos haviam sido registrados, para uma população de 470.872 habitantes. Só no mês de outubro, quando se manifestou a epidemia no Recife, foram registrados 1.251 óbitos devido à gripe, cuja população era de 218.255 habitantes entre 1918 e 1919.

A leitura de centenas de edições de jornais e revistas em curso nesta pesquisa pode trazer pistas de como as autoridades governamentais e a população conduziram a vida cotidiana em meio à pandemia. A situação causada pela gripe espanhola, destacadamente nas capitais por onde o vírus atracou, foi a de calamidade, como decretada no Rio de Janeiro. Com muitas semelhanças ao cenário pandêmico ocasionado pelo coronavírus em 2020.

$\mathrm{Na}$ então capital brasileira, por exemplo, houve falta de alimentos e medicamentos. Todo o comércio se fechou por alguns dias. Os meios de transportes se tornaram escassos, dificultando as comunicações. Os serviços postais e telegráficos ficaram atrasados. O trabalho nas fábricas, estabelecimentos industriais e repartições públicas foi reduzido ou suspenso. O serviço mortuário tornou-se extremamente insuficiente para atender às exigências do momento. Faltou caixões, não havia veículos suficientes para a condução de cadáveres às sepulturas; grande número de enfermos jaziam abandonados, sem assistência médica.

Sem perspectiva de vacina, adotou-se a profilaxia. Documentos publicados pelos governadores evidenciam que a Diretoria de Saúde determinou práticas de desinfecção em larga escala, e que deveriam ser repetidas especialmente nas casas ou estabelecimentos onde havia aglomerações de pessoas, tais como casas de diversão, igrejas, repartições públicas, mercados e veículos públicos.

Edição de 02 de novembro de 1918 da Fon-Fon! publicava, sob o título "A quinzena trágica", notícia sobre como a doença atingia o Rio de maneira impiedosa, causando danos incalculáveis, como mortes, prejuízos materiais, tristeza e fome. A população se viu desprotegida e entregue aos seus próprios recursos, graças, segundo a matéria, ao fato de que o serviço de assistência pública ser limitado aos socorros urgentes da Assistência Municipal e de algumas instituições particulares. 


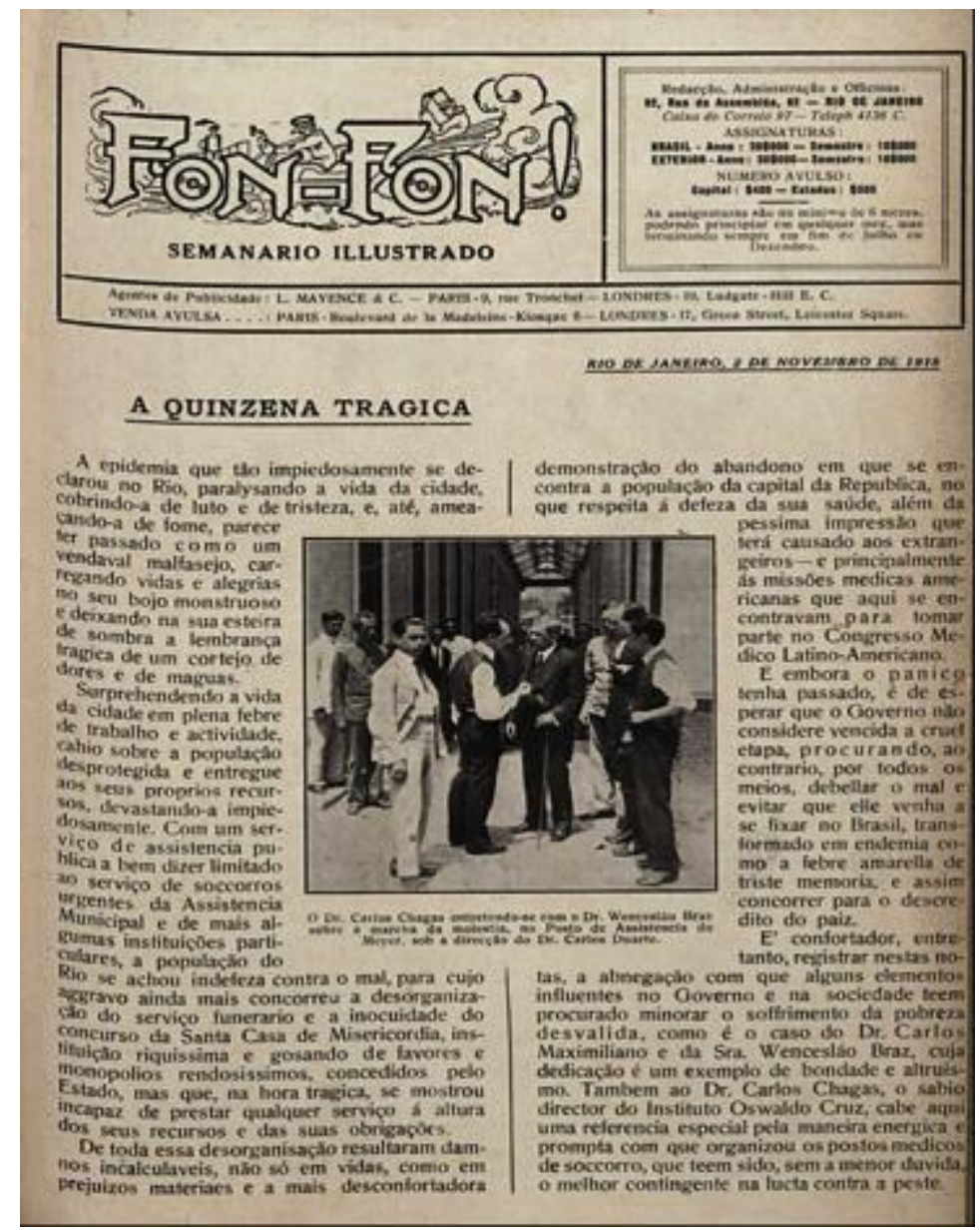

Figura 13: Edição da Revista Fon-Fon! de 02/11/1918. Fonte: catalogação do Grupo de Pesquisa Jornalismo e Humor nos arquivos digitais da Biblioteca Nacional

A mesma edição traz uma propaganda intitulada "Como evitar e curar a influenza hespanhola?', na qual indica que as "Balas Peitorais evitariam e curariam a influenza, pois eram bombons com ação antisséptica. Também se recomendava o uso do "Sal de Uvas", purgante de frutas aconselhado para as crianças, que ajudaria a manter o organismo em condições de resistir a terrível doença". 


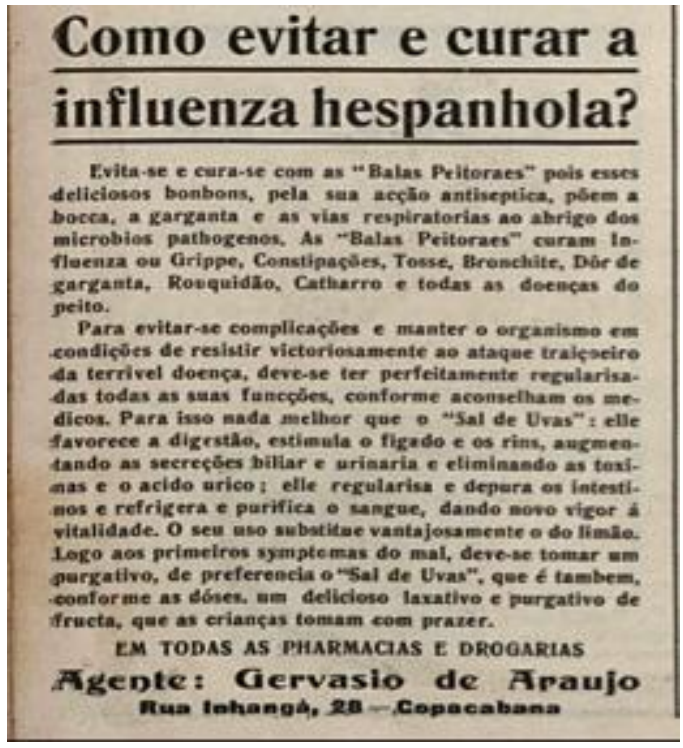

Figura 14: Anúncio publicado na Revista Fon-Fon! de 02/11/18. Fonte: catalogação do Grupo de Pesquisa Jornalismo e Humor nos arquivos digitais da Biblioteca Nacional.

Em 17 de outubro de 1918, com a manchete "Os três flagelos: fome, peste e guerra" o jornal paulistano O Combate dava o tom da situação calamitosa. Nesta edição, publicava matéria com o título "A indecorosa especulação dos droguistas e farmacêuticos". Eram críticas sobre o aumento do preço de quinino e mentol, então utilizados contra a gripe. Os farmacêuticos queixavam-se dos droguistas, mas o texto acusava o poder público por não impedir a alta especulação em torno dos medicamentos. 


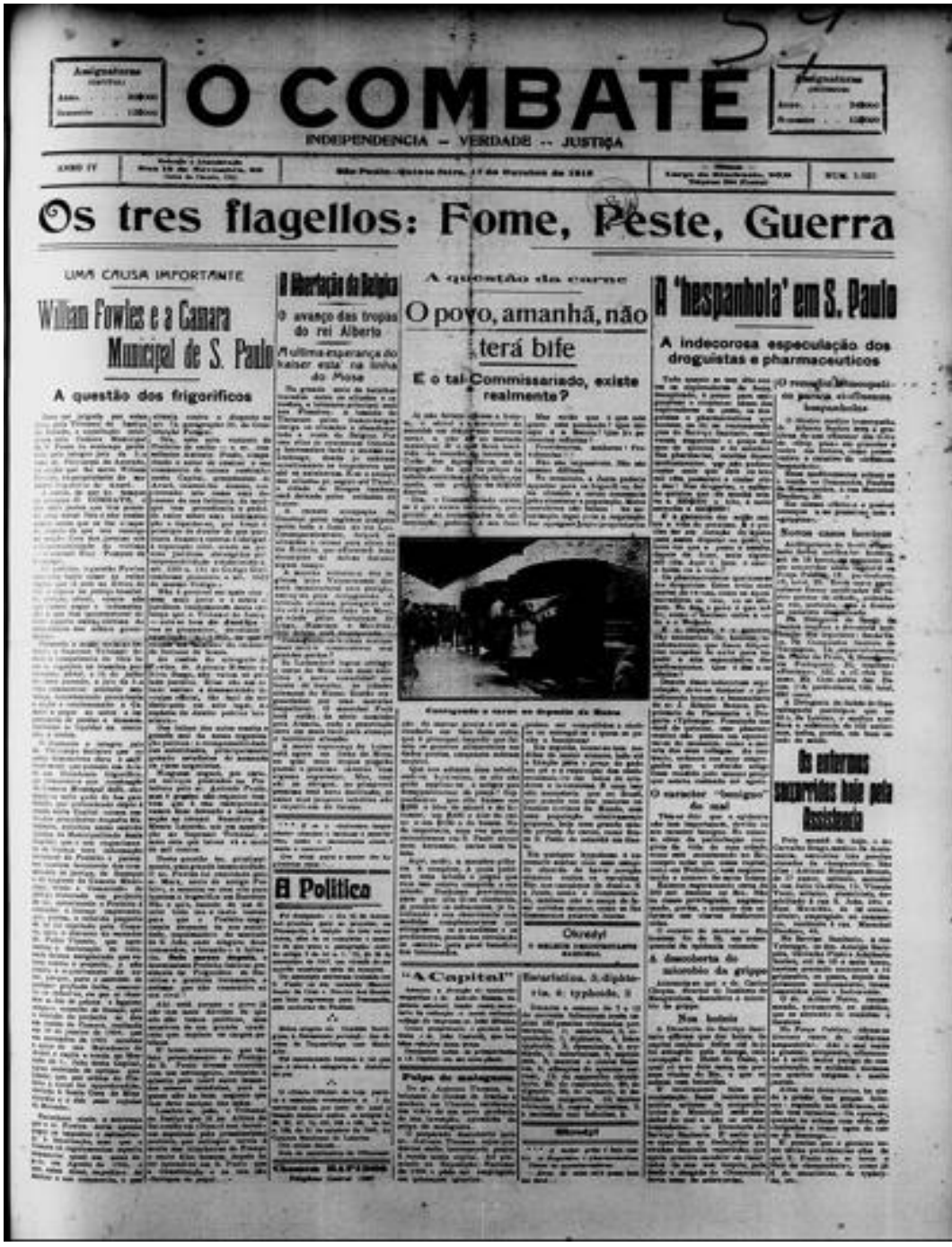

Figura 15: Edição do jornal O Combate de 17/10/18. Fonte: catalogação do Grupo de Pesquisa Jornalismo e Humor nos arquivos digitais da Biblioteca Nacional.

\section{Recorrências e permanências}

Na segunda metade da Velha República, o governo proibiu as aglomerações e restringiu a circulação de pessoas, medidas adotadas devido à proliferação da gripe, que não poupou ninguém. Atingiu todas as classes sociais, superlotou os hospitais e suas portas foram fechadas para visitantes, na tentativa de evitar novos contágios. Além disso, as escolas foram fechadas e adotou-se a aprovação de todos os alunos naquele ano 
letivo. No comércio apenas farmácias e mercearias funcionavam. Separadas por um século, as pandemias possuem recorrências nas questões sanitárias, políticas e sociais.

Segundo as medidas sanitárias da época, as pessoas que sentiam os primeiros sintomas da gripe espanhola deveriam repousar. Também era necessário evitar contato com outras pessoas para não ocorrer novos contágios. A doença se concentrava nas cidades portuárias e isso fez as autoridades decidirem fechar os portos No entanto, ocorreu a acusação de exploração política da doença, em que as autoridades tentavam esconder que obrigavam a atracação de navios, principalmente os do Lloyd Brasileiro. A oposição denunciava esse comportamento, dando a alcunha de "porto sujo".

O jornal Imparcial cobriu o ocorrido à época, declarando na manchete: "A influenza na Bahia é política" (SOUZA, 2009, p.103). A situação se repete no ano de 2020 com a Covid-19, em que ações das autoridades são camufladas pela pandemia. Na reunião ministerial em 22 de abril, Ricardo Salles, Ministro do Meio Ambiente, declarou que seria uma boa estratégia "passar a boiada" na legislação ambiental e aproveitar que as atenções estavam voltadas ao momento crítico que se encontrava o país no combate à pandemia (CNN, 2020, documento eletrônico).

No contexto político a irresponsabilidade das autoridades em não acolher as recomendações estabelecidas pelos serviços internacionais é um problema que se repete no Brasil. No começo da pandemia da influenza, Carlos Seidl, diretor geral da saúde pública, decretou que não seria necessário tomar medidas drásticas como isolamentos e quarentenas, alegando que seria ilegal e não científico. Isso tomou uma proporção grandiosa e ele foi pressionado a pedir demissão, no dia 17 de outubro de 1918, em um dos momentos mais críticos do agravamento da gripe no Brasil. Seidl, inclusive, utilizou o termo "gripe comum" (Figura 16) em comunicado enviado aos jornais, para minimizar a gravidade que a imprensa estabelecia à situação, acusando-a de causar pânico. 


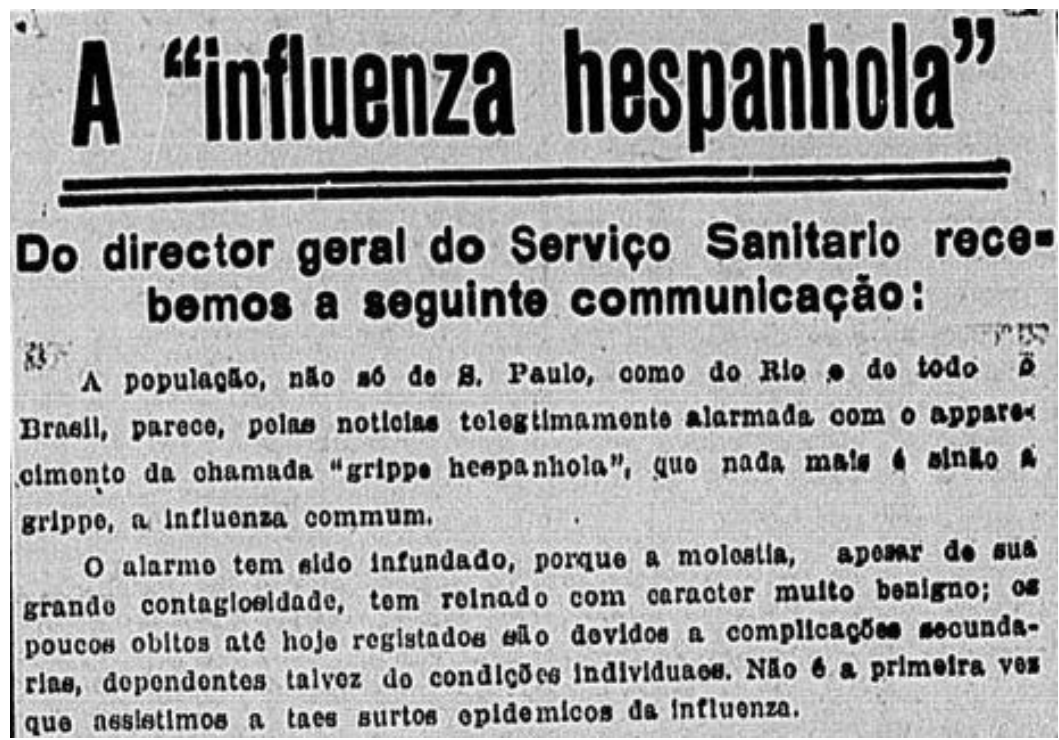

Figura 16: Comunicado de Carlos Seidl em edição do jornal O Correio Paulistano 16/10/1918. Fonte: catalogação do Grupo de Pesquisa Jornalismo e Humor nos arquivos digitais da Biblioteca Nacional.

\section{Pandemia na imprensa ontem e hoje}

A 1ํ Guerra Mundial (1914-1918) fez os índices da doença cresceram exponencialmente, pelo trânsito de navios e as aglomerações insalubres dos campos de batalha. Já com a Covid-19 houve uma $1^{\circ}$ onda extraordinária na Europa, sobretudo na Itália, que no auge marcou quase 1000 mortes diárias (G1, 2020).

A desinformação sobre o vírus e formas não comprovadas de se prevenir eram disseminadas nos jornais, por vezes pela falta de bases científicas da época. Não se sabia sobre as melhores formas de prevenção e nem como afetaria determinada região do país, semelhantemente ao período anterior da chegada da Covid-19 ao Brasil, em que havia suspeitas de que em em altas temperaturas o vírus iria se manifestar de maneira morosa. 


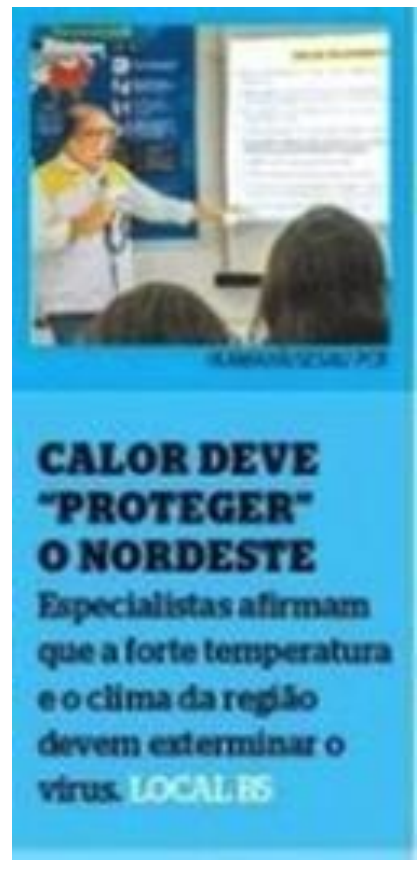

Figura 17: Destaque da primeira página do Diario de Pernambuco de 05/02/2020, detacando que o "calor deve 'proteger' o Nordeste", entendimento que caiu por terra logo na sequência

No momento em que a gripe espanhola (1918) e a Covid-19 (2020) adentraram o território brasileiro, em cada época, as notícias sobre a quantidade de suspeitas e infectados aumentaram consideravelmente. Os jornais não pouparam páginas para retratar as dificuldades enfrentadas e quais seriam as providências tomadas para que não ocorresse a disseminação. A partir da confirmação de casos, optaram por informar sobre a situação das escolas, fábricas e de todo meio social. Os jornais evidenciam os problemas sociais causados pela doença, sobretudo para informações de utilidade pública, como onde ficavam os hospitais para atendimento, a situação dos transportes públicos, dos medicamentos e higiene nas farmácias.

Para além dos factuais, os jornais se posicionavam para auxiliar os leitores a se protegerem do vírus que se alastrava pelas cidades. Eram comuns (1918) e ainda permanecem correntes (2020) orientações sobre qual melhor maneira de fazer assepsia 
das mãos e das residências, além de todo cuidado em evitar aglomeração e contatos com pessoas infectadas.

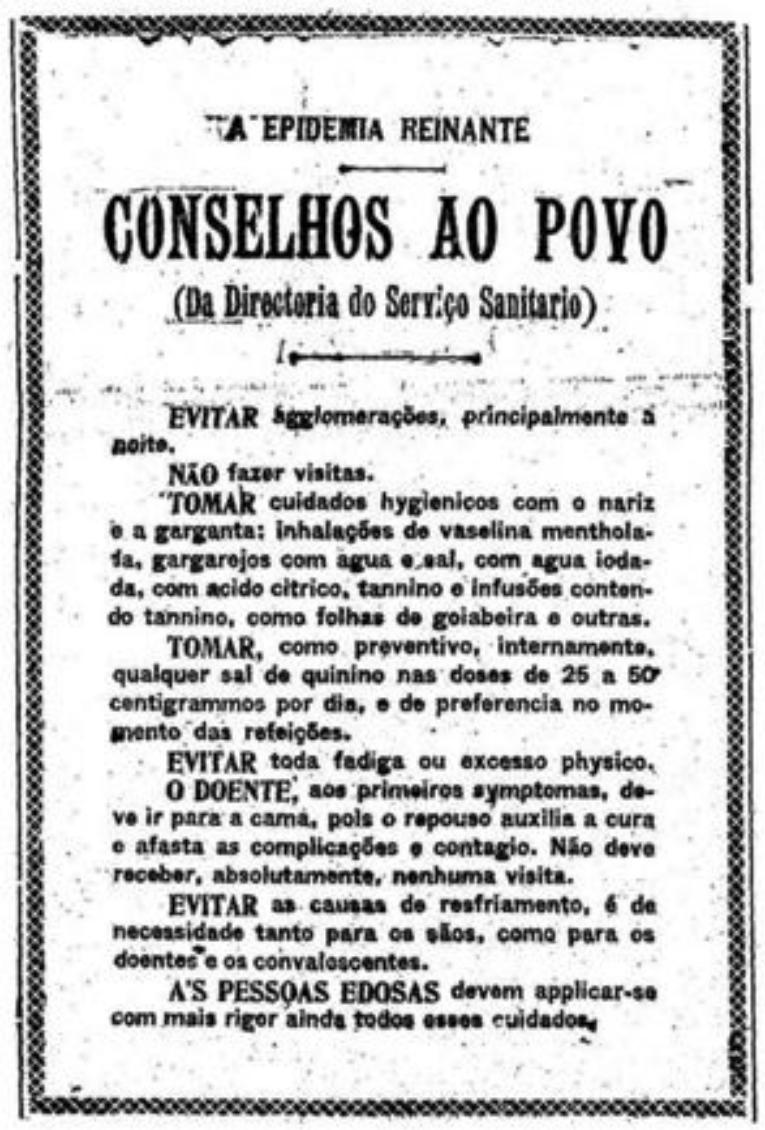

Figura 18: Nota com recomendações para combater a espanhola, 18/10/1918. Fonte: Acervo de fotos - O Estado de S.Paulo.

Um grande aliado dos jornais que buscavam retratar as consequências da doença foi o fotojornalismo, que dava um tom ainda mais dramático ao ilustrar a realidade da sociedade brasileira. As fotografias documentaram os impactos sociais e psicológicos que a gripe acarretou nas cidades. Em 1918, a Fon-Fon! publicou nas edições 43 (26 de outubro), 44 (02 de novembro - Figura 19), 45 (09 de novembro) e 47 (23 de novembro) imagens de distribuição de medicamentos e mantimentos, procissões, enfermos em hospitais e postos de assistência, caminhões para o transporte dos corpos, enterro e os cemitérios de Inhaúma e Cajú. 


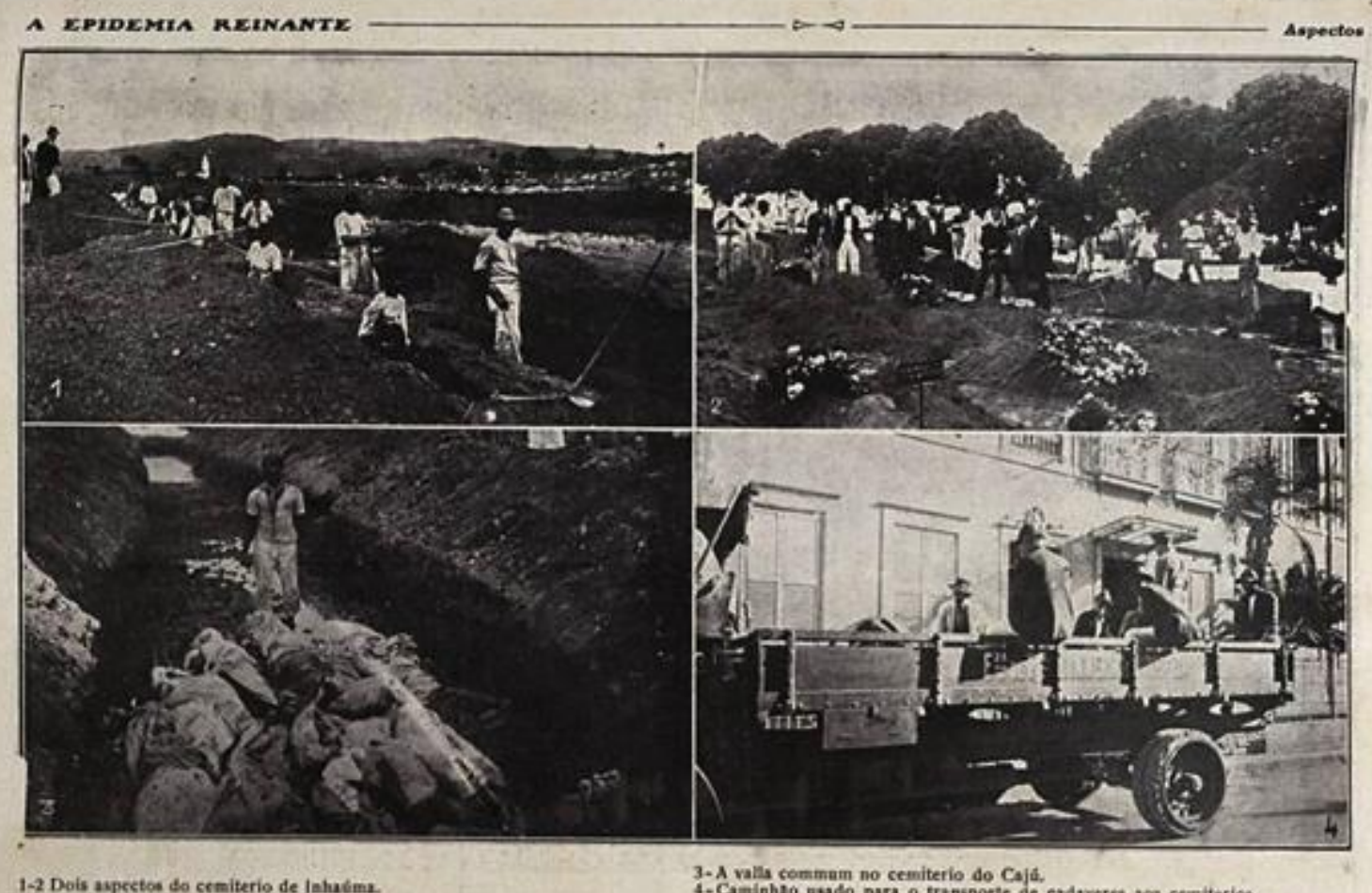

Figura 19: Imagens do cemitério de Inhaúma e Cajú (RJ) e caminhões de transporte de cadávares na edição de 02 de novembro de 2018, Dia de Finados, da revista Fon-Fon!. Fonte: catalogação do Grupo de Pesquisa Jornalismo e Humor no acervo digital da Biblioteca Nacional.

Desde que a Constituição Federal de 1988 foi promulgada, a ideia institucional sobre liberdade de expressão e a liberdade de imprensa é difundida pelo Brasil. Não há dúvidas de que, independentemente do momento, a democracia brasileira é ameaçada, e não foi diferente nas duas situações. Enquanto a influenza (1918) assolava o Brasil, Carlos Seidl ordenou a censura de vários jornais. Inclusive, confessou em carta enviada ao Ministro da Justiça, Carlos Maximiliano, que pediu ao presidente censura das notícias sobre a gripe, acusando os jornais de ataque pessoal. 


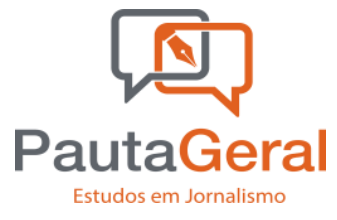

\section{NA CAPITAL}

DA REPUBLICA

As movidexolas tomadas PELO SR. PIESIDENTE DA MBPULILA - AS OONFE. RENOIAS HAVEAS HOJE COM SUA EXO

o dr. Carlos soldi alriglu ao dr. Caxlmlllano, minlotro da Juetlaca, a segulnte carta:

"Blo 18 do outubro do 1918 ino, ds Carlos staximllina Hontem, a nolto, desdo que live a prova do que o exmo. er. prest. dento da' Republles communga $\mathrm{n}$ oplntäo doe que me julgam culps:do da Invaes̃o da Influenza ou gripps epldemica em nosso palz, nilio duvidel em depor, nas malos de o. exo., o cargo do director $\mathrm{g0}^{\circ}$ ral da Baude Publica, quo vinha exercondo ha perto do 7 aninco. som brllho, mas com multa dodicação - maximo desojo de acoet:

si nso o fla antes, Jesdo quo se formou a hostilldade insolita da maioria da Imprenea carloca, Dedindo a minha demlesúo pelo motivo acima a pontado, Pol porqua a minha conctoris 0 hygieno 0 medlecta nato ann dato

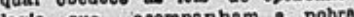
logla, quo

Nao pedi tambom, antes, demlo. Nao pedi tambom, antee, demioedio, Dorque tora covarda abando nar Do do de eacriclo alo drector do sac mento do male rabalho, do malor

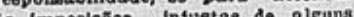
(a) Jornaci, Dor quo una lalta quo sto comem, 16 quo ve cxo alo talel de eltua. cio creas para mlm pela grita aa imprones carloca levada 20 ponto ancar a publlco a Invoro dade do ane a Academla Naclonal de do IIrara-me aconselhando-me a $\mathbf{8 0}$. gulr o "non ragglonar di lor, ma guarda o paesa".

Fol nessa ocesaläo que oumprl o cover do pedir, a v. exc., que ortonaeso a cenours o Impodimento do nottclarlo abreadabranto o 6eneaclonal, reforento a epldemla, de!xando a llberdado do ataque a ml. nha peecon, lembranga essa quo A occorrors a v. exc., conformo teve a bondade de declarar-me.

Quanto a culpa que 00 mo ditribue, da pandemia que nos intolleita, do v. exo. ouv1 malo de uma vez a declaraça de nato reconthecer csea culpa, Ignorando ou ato hontom, noite, que, do ponear contrarlo, 6. exc. o er. presidento, que Iniporta na perda da contianca necresarla para contluuar no cargo para quo tal chamado, oota a minima sollestacas do milha parto o ao dual dol todo o morco de quo era capaz, - quo dolxo eom satudades:

Digne-eo v. exc. acceltar o tee. comunhio do minha mul respeitosa v. exc. etc. - (a.) Carlos Sclal."

Figura 20: Nota da edição 19.843 do Correio Paulistano, de 02/10/1918. Fonte: Fonte: catalogação do Grupo de Pesquisa Jornalismo e Humor no acervo digital da Biblioteca Nacional 
Comparando com o momento atual, em que há ataques governamentais à cobertura da imprensa - o presidente brasileiro chegou a afirmar que o coronavírus seria uma criação midiática (SANCHES, 2020, documento eletrônico) -, a censura tem sido utilizada de maneira direta e, também, sub-reptícia. O Governo Federal chegou a parar de divulgar a quantidade de casos e mortes pela doença para atrapalhar a cobertura da imprensa. Além disso, o próprio presidente solicitou ao Ministério da Justiça investigar uma charge do cartunista Renato Aroeira, em que associava a postura do mandatário ao nazismo. Esse tipo de censura indireta, com a não divulgação dos casos atualizados, e a direta, como em relação à charge, demonstra como em casos de calamidade pública a atuação da imprensa vem sendo constantemente ameaçada no País.

\section{Divergências com a cobertura contemporânea}

$\mathrm{Na}$ pandemia de 1918, ainda não havia um setor governamental responsável pela administração e manutenção da saúde pública no Brasil, o que resultava em dados desencontrados sobre as mortes decorrentes da gripe espanhola. Em contrapartida, todos os dias durante a pandemia da Covid-19 são divulgados pela imprensa e pelo Ministério da Saúde (MS, 2020, documento eletrônico) - embora com dissonância - informações sobre o vírus, como dados de vítimas em cada estado, número de recuperados, como se prevenir e permanecer na quarentena, entre outros.

Nas revistas semanais cariocas também raras eram as publicações a respeito da contabilização do número de vitimados pela gripe espanhola. Na edição 542 da Careta, publicada em 09 de novembro de 1918, informa-se que em menos de um mês, só na capital da República, já eram 20 mil cadáveres. A matéria assinada por Frei Antônio também criticava a situação sociopolítica. 


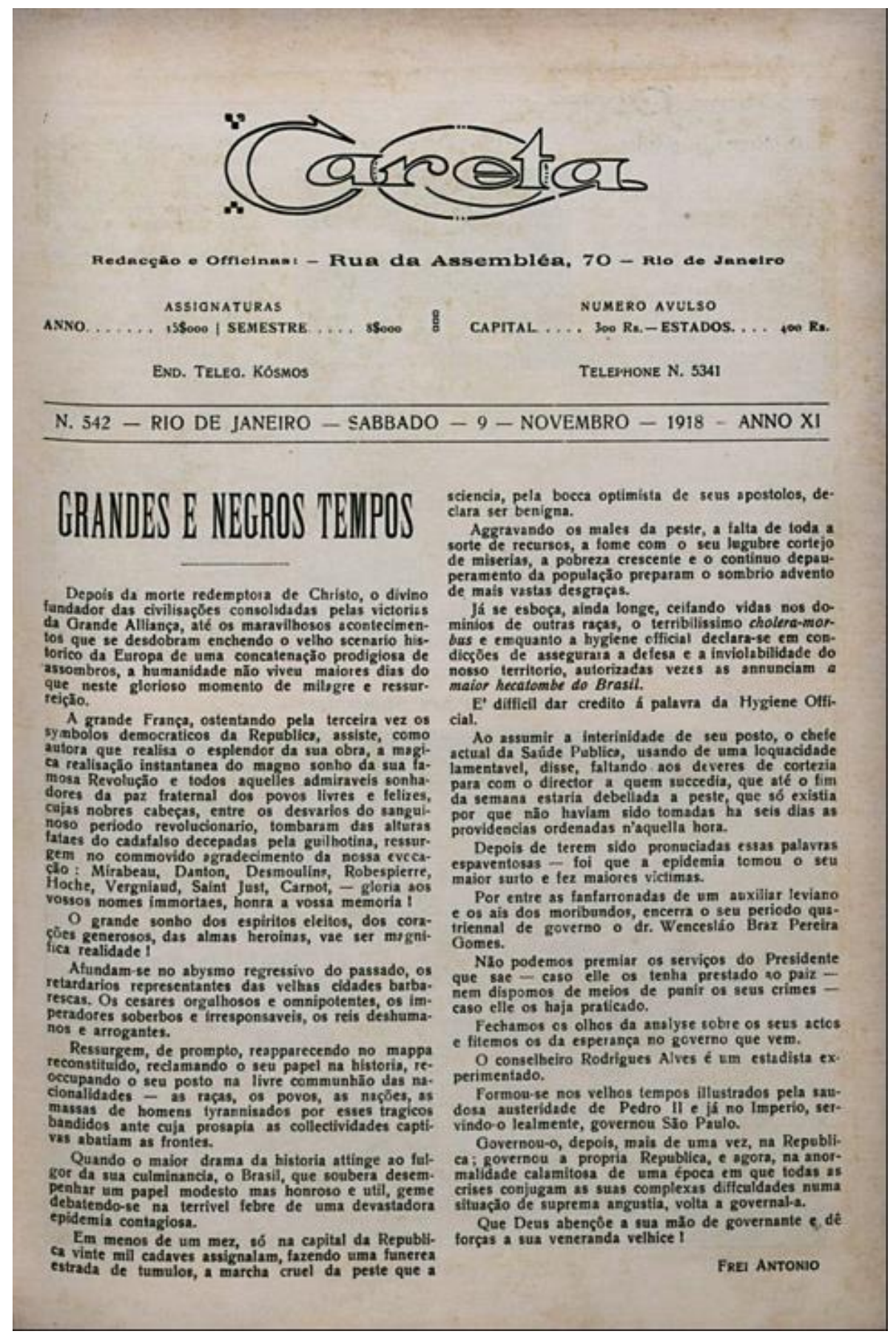

Figura 21 : Revista Careta de 09/11/18. Fonte: Coleção Digital de Jornais e Revistas da Biblioteca Nacional 
O auxílio e a manutenção da saúde pública pelo governo era muitas vezes abordado pelos jornais com sendo realizados de maneira precária, com hospitais superlotados, muitos corpos abandonados ao relento nas ruas, com a culpabilização aberta ao diretor de saúde no período, Carlos Seidl, severamente criticado pela imprensa pela má administração da diretoria. Ele chegou a dizer que não era preciso quarentena, como relata a pesquisa de Adriana da Costa Goulart (2005, documento eletrônico):

Em sessão da Academia Nacional de Medicina de 10 de outubro de 1918, Seidl apresentava uma lista de nove conclusões sobre a doença que grassava na capital, afirmando que, "em sua marcha caprichosa e vagabunda, a influenza (...) menospreza todos os regulamentos, todas as medidas e todas as quarentenas, sendo o isolamento irrealizável na gripe epidêmica, a menos que se interrompam (...) todas as relações sociais e todos os contatos daí oriundos" (Seidl, 1918, p. 591).

As pessoas que buscaram isolamento, à época, o fizeram por conta própria, sem intervenção do estado como na pandemia do coronavírus. Conforme mencionado anteriormente, Seidl logo veio a deixar o cargo, no auge da contaminação, entre outubro e novembro de 1918, período no qual grande parte das notícias voltaram seu enfoque para a gripe.

Os veículos divulgavam o número de mortes e os dados de algumas vítimas, como nome e rua em que moravam. Grande parte dessas pessoas detinham algum prestígio social e ganhavam histórias contadas em pequenas notas. A partir do crescimento exponencial dos enfermos, passaram a divulgar em menor frequência o nome das vítimas.

A realidade passada pelos jornais é de que não se tinha controle algum sobre os números de vítimas, o que difere da pandemia de 2020, que conseguiu ter um alcance maior em consequência das tecnologias atuais, que facilitam tanto na disseminação de informação, quanto em acesso e controle desses dados. Durante o período 1918 - 1919 , as notas nos jornais evidenciaram que a contagem das vítimas eram feitas pelas delegacias de polícia. Também há de se destacar a veiculação de casos de suícidio após contraírem a doença (Figura 22): 
Figura 22: Matéria da edição 293 do jornal Gazeta de Notícias de 22/10/18. Fonte: Coleção Digital de Jornais e Revistas da Biblioteca Nacional.

Em 19 de outubro de 1918, a Careta, na edição 539, publicou a matéria "A propósito da influenza hespanhola", em que criticava um jornal que aconselhou ao Governo que os médicos responsáveis por pacientes contaminados da gripe deveriam usar um distintivo, para que assim as pessoas mantivessem um distanciamento dos profissionais da saúde, evitando novos contágios. A revista alegava que essa ideia profilática era algo ultrapassado.

\section{Grota.}

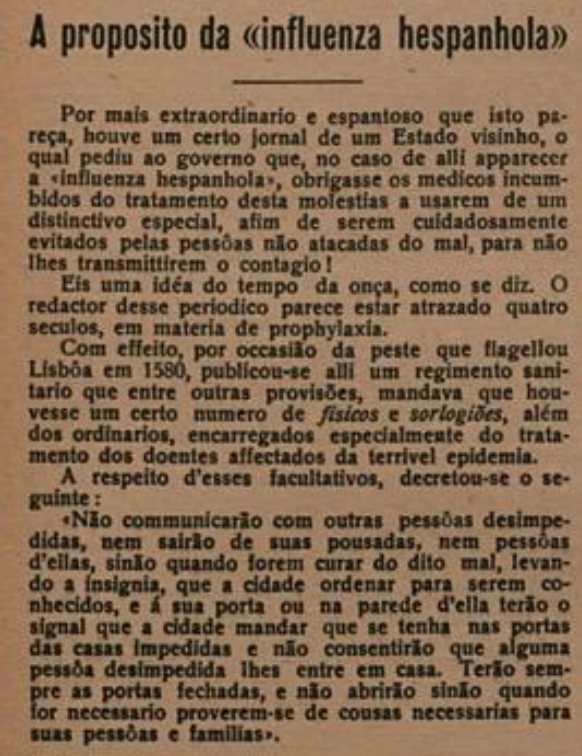

Era um verdadeiro bloqueio, quasi uma excommunhalo imposta aos medicos, na sua espinhosa e humanitaria missilo! Mas isso era no tempo da theoria dos miasmas, antes das maravilhosas descobertas prophylaticas da seiencia moderna. Essas prescripçóes dose de criterio der, naquella cpocha, ama certa dose de criterio e de bona senso: temia-se que os Da obrigaç̄o imposta sos medicos lisboetse net:a occasiăo de usarem uma insignia para serem conhecidos, provem o uso geral que se estabelecen em Lisbỏa de andarem elles vestidos de um modo espedal, para se nilo confundirem com os individuos de

Esse antigo uso veiu afinal a se extinguir. Posteriornente, em 1766, o juiz do povo Joaquim Percira Caróso, dirigiu a Camara de Lisboa, para tazer subir a presença de el-rei, uma represenlachao em que dizia o seguinte; Entre as mulas desordens e prejuizos que a chrs, nio foi o menor o pasearem os medicos e ci rutos a trajerem como aualouer outra pesso a do

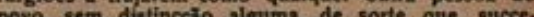
dendo alrum caso de doenca repenting morria. doente por falta de medico, pois que ainda que pela rua trantitassem muitos, a pé on a cavallo, nío se differencavam para serem chamados; e o mesmo conteceria dando-se qualquer aceidente ou desgraça em logar publice. Taes inconvenientes se evitariam, andando on medicos e cirurgióes, como costumavam antes do terremolo, de capa e voltas. A Camara informou favoravelmente, mas a pretençio nunca teve despacho. C.

Figura 23: Matéria da Revista Careta de 19/10/18. Fonte: Coleção Digital de Jornais e Revistas da Biblioteca Nacional. 
No fim de 1918 e início de 1919, a impressão era de que a doença tinha sido superada. Como destaca a edição 52 da Fon-Fon!, publicada em 28/12/18, que informa: "Passada a terrível epidemia de gripe, em cujo período chegou a notícia da vitória dos aliados, a qual não pode se festejar, realizaram-se agora na capital grandes homenagens, (...) na Avenida Tiradentes, 100.000 pessoas compareceram às ruas".

\section{Algumas conclusões}

A produção jornalística é um produto do contexto social e histórico da época em que foi realizada (SCHUDSON, 1978). No entanto, também é feita de aspectos e tendências que parecem imutáveis, repetindo-se em diversos espaços temporais. Durante as pandemias da Gripe Espanhola e da Covid-19 esse panorama não foi diferente: a análise do material selecionado possibilitou a detecção de diversas permanências e divergências de comportamento entre os dois momentos históricos.

Assim como na atualidade, veículos jornalísticos prestaram um papel importante à população na época da influenza, assumindo uma postura crítica em relação às ações de poderes públicos e instituições no combate à pandemia. Figuras e entidades públicas foram duramente criticados por jornais e revistas por diversos erros em relação à pandemia: quer fosse pela minimização da gravidade da doença, pela falha em implementar medidas eficazes de prevenção ou até mesmo por atitudes de má fé, como a questão da descarga clandestina de mercadoria nos portos denunciada pelo jornal $O$ Imparcial.

Posturas de crítica e cobrança também estão bastante presentes na cobertura da pandemia atual e demonstram um comprometimento da imprensa, pelo menos nesses termos, com o interesse público, o que inclusive chegou a acarretar, em ambas as épocas, tentativas de censura ou boicote por parte dos entes públicos.

Outros aspectos encontrados também se fazem presentes nos veículos em 2020, como as orientações para a prevenção. A população recebeu a devida atenção dos veículos através de outros tópicos, como o retrato dos problemas sociais e econômicos decorrentes da pandemia e o mapeamento e divulgação de números de óbitos em decorrência da doença, presentes em ambos os momentos históricos, ainda que realizada de forma mais esparsa e rudimentar durante a pandemia da gripe espanhola por conta das limitações da época. 
Apesar das várias continuidades, as diferenças entre o mundo de 1918 e 2020 também foram cruciais na construção da cobertura das duas pandemias. O jornalismo, durante a pandemia da influenza, chegou a buscar as visões do meio científico para nortear suas análises, mas por conta do alcance da própria ciência do alvorecer do século 20, vários veículos indicaram remédios e receitas ineficazes para cura ou prevenção da doença.

A circulação de fake news também tem sido frequente durante a pandemia da Covid-19, mas no contexto atual tem sido realizada por outros agentes, com boa parte da imprensa atuando no sentido contrário, desmentindo rumores e informações falsas com base em informações cientificamente comprovadas - algo que só foi possível com as descobertas alcançadas pela ciência com o passar das décadas. Os avanços da pesquisa e tecnologia possibilitaram mais ferramentas para realização da cobertura, o que acarretou na divulgação de números de contaminações e óbitos mais consistentes que os da época da gripe espanhola, bem como na obtenção de notícias de um maior número de localidades e num processo de apuração mais célere.

O presente estudo também revelou que, mesmo diante de uma tão situação dramática quanto uma pandemia, o humor esteve presente na imprensa. As revistas FonFon e Careta souberam utilizar piadas, charges e outros tipos de conteúdo cômico para tratar da gripe, tanto como forma de refúgio diante da situação assustadora que se enfrentava quanto como meio de informar e refletir criticamente.

Como qualquer campo de estudo, o jornalismo passou por adaptações e evoluiu juntamente com outras áreas da ciência e com a própria esfera pública, suprindo na pandemia atual necessidades impossíveis de serem alcançadas pelo ofício de reportar em outros tempos. Entre o quinino e a cloroquina, a gripe espanhola e o novo coronavírus, a imprensa continua se provando uma instituição fundamental para a manutenção de sociedades democráticas.

\section{Referências}

CNN BRASIL. Reunião ministerial de Bolsonaro: assista ao vídeo na íntegra e leia transcrição. Disponível em: <https://www.cnnbrasil.com.br/politica/2020/05/22/assistaao-video-da-reuniao-ministerial-com-bolsonaro>. Acesso em: 18 out. 2020. 
CORREIO PAULISTANO. A “influenza espanhola”. Edição 19.857, de 16 de outubro de 1918, p.01.

FON-FON!. Ano XXII, Número 40, de 05 de outubro de 1918. Fonte: Fundação Biblioteca Nacional/Hemeroteca Digital Brasileira. Disponível em $<$ http://memoria.bn.br/DocReader/DocReader.aspx?bib=259063\&pagfis=31190 >. Acesso em 07 de julho de 2020.

G1. Itália tem quase mil mortes causadas pela Covid-19, o recorde diário. 2020. Disponível em <https://g1.globo.com/mundo/noticia/2020/03/27/italia-tem-quase-milmortes-causadas-pela-covid-19-o-recorde-diario.ghtml>. Acesso em: 23 de outubro de 2020

GOULART, Adriana da Costa. Revisitando a espanhola: a gripe pandêmica de 1918 no Rio de Janeiro. Hist. cienc. saúde-Manguinhos vol.12 no.1 Rio de Janeiro Jan./Apr. 2005. Disponível em: <https://www.scielo.br/scielo.php?script=sci arttext\&pid=S010459702005000100006>. Acessado em 24 de outubro de 2020.

IAMARINO, Átila. H1N1, mais de 90 anos entre nós: a origem e história desse vírus. $2009 . \quad$ Disponível em <https://www.blogs.unicamp.br/rainha/2009/08/h1n1 mais de 90 anos entre nos/>.

Acesso em 23 de outubro de 2020.

JANASI, Lígia. Gripe espanhola: a pandemia do século XX. 25 de março de 2020. Disponível em <https://www.politize.com.br/gripeespanhola/\#: :text=A\%20primeira\%20vacina\%20contra\%20a\%20gripe\%20espanhola\%20 foi\%20fabricada\%20somente\%20em\%201944>. Acessado em 21 de outubro de 2020.

JORNAL PEQUENO. Influenza Hespanhola. Edição 230, de 07 de setembro de 1918. Capa. Disponível na Hemeroteca Digital da Biblioteca Nacional.

MINISTÉRIO DA SAÚDE. Coronavírus covid-19 o que você precisa saber. Disponível: <https://coronavirus.saude.gov.br/>. Acesso em: 15 out. 2020.

OMS. Weekly Epidemiological Report. No 16, 17 abr 2020, 95 pp. 145-160. Disponível em < http://extranet.who.int/iris/restricted/bitstream/handle/10665/331774/WER9516-engfre.pdf?ua=1>. Acesso em 9 jun 2020.

REVISTA BRASIL. Brasil faz sequenciamento do genoma do Covid-19 em tempo recorde. 2020. Disponível em <https://radios.ebc.com.br/revistabrasil/2020/03/sequenciamento-do-genoma-do-covid-19-em-tempo-recorde-e-passoenorme-para $>$ Acessado em 10 de outubro de 2020.

REVISTA GALILEU. 7 fatos sobre a Gripe Espanhola no Brasil. 2020. Disponível em $<$ https://revistagalileu.globo.com/Sociedade/Historia/noticia/2020/06/7-fatos-sobre-gripeespanhola-no-brasil.html>. Acessado em: 15 de outubro de 2020. 
SANCHES, Mariana. 'É muito mais fantasia', diz Bolsonaro sobre crise nos mercados causada por epidemia do coronavírus. BBC News. 10 mar. 2020. Disponível em https://www.bbc.com/portuguese/internacional-51823908>. Acesso em 25 out. 2020.

SCHREIBER, Mariana. Por que Bolsonaro está sendo acusado de colocar indígenas em risco em meio à pandemia de covid-19. BBC. Disponível em: <https://www.bbc.com/portuguese/brasil-53375095>. Acesso em: 18 out. 2020.

SOUZA, CMC. A influenza na Bahia é... Política!. In: A Gripe Espanhola na Bahia: saúde, política e medicina em tempos de epidemia [online]. Rio de Janeiro: Editora FIOCRUZ, 2009, pp. 91-129.

SOUZA, Felipe. Coronavírus: pandemia vai superlotar hospitais brasileiros e governo deve restringir eventos em breve, diz infectologista. BBC. Disponível em: <https://www.bbc.com/portuguese/brasil-51827162>. Acesso em: 15 out. 2020.

SCHUDSON, Michael. Discovering the news. A social history of american newspapers, New York: Basic Books Inc. Publishers, 1978.

WESTIN, Ricardo. Em 1918, gripe espanhola espalha morte e pânico, faz escolas aprovarem todos os alunos e leva à criação da caipirinha. Agência Senado, 03 set 2018. Disponível em https://www12.senado.leg.br/noticias/infograficos/2018/09/epidemiade-gripe-espanhola-no-brasil-mata-presidente-faz-escolas-aprovarem-todos-os-alunos-eleva-a-criacao-da-caipirinha. Acessado em 25 out 2020. 